\title{
SISTEM PAKAR PENENTUAN JENIS PLANKTONIC FORAMINIFERA BERBASIS WEB DENGAN METODE FORWARD CHAINING
}

\author{
Daniel Alexander Octavianus Turang \\ Program Studi Teknik Informatika \\ Sekolah Tinggi Teknologi Bontang \\ daniel.alexanderot@gmail.com
}

\begin{abstract}
Abstrak
Mikropaleontologi merupakan salah satu cabang dari ilmu paleontologi yang mempelajari mikrofosil. Salah satu pengetahuan yang terdapat pada ilmu mikropaleontologi adalah planktonic foraminifera (fosil plankton). Metode yang digunakan dalam penelitian ini adalah metode Forward Chaining. Sistem yang akan dibangun merupakan suatu sistem informasi yang berbasis komputer dengan memanfaatkan teknologi kecerdasan buatan (artificial intelligence) yang berfungsi sebagai sistem alat bantu atau pemberi rekomendasi dari proses identifikasi planktonic foraminifera kepada user. Data rekomendasi yang dihasilkan oleh sistem ini dilengkapi dengan nama spesies planktonic foraminifera, nama genus, gambar planktonic foraminifera, beserta sifat-sifat fisik dari planktonic tersebut sehingga user dapat mengetahui spesies planktonic foraminifera apa yang ditemukan. Sistem akan menganalisa jawaban dari setiap pertanyaan yang diberikan, sehingga diperoleh hasil dari identifikasi berdasarkan basis pengetahuan yang ada dalam sistem pakar ini. Tugas dari user hanya memasukkan planktonic foraminifera apa saja yang terdapat pada batuan tersebut. Dan setelah itu, sistem akan menghitung range umur relatif berdasarkan range umur dari setiap planktonic foraminifera yang telah dimasukkan.
\end{abstract}

Kata Kunci : forward chaining, mikropaleontologi, planktonic foraminifera.

\section{Abstract}

Micropaleontology is one of the branches of the science of paleontology which studies Microfossils. One of the knowledge contained on the planktonic foraminifera is micropaleontology science (fossils of plankton). The methods used in this research is a method of Forward Chaining. The system to be built is a computer-based information system by utilizing the technology of artificial intelligence that serves as the system tools or giver recommendations of the identification process planktonic foraminifera to the user. Data recommendations generated by the system is equipped with a planktonic foraminifera species name, genus name, images of planktonic foraminifera, along with the physical properties of the planktonic so the user can identify the species of planktonic foraminifera what was found. The system will analyze your answers to each question are given, so that the obtained results from identification based on the existing knowledge base in expert system. The task of the user only put in planktonic foraminifera anything contained on these rocks. And after that, the system will calculate the relative age range upon range of planktonic foraminifera of any age that have been entered.

Keywords: forward chaining, micropaleontology, planktonic foraminifera

\section{Pendahuluan}

Mikropaleontologi merupakan cabang dari ilmu paleontologi dalam ilmu geologi yang mempelajari sisa-sisa organisme yang telah terawetkan di alam berupa fosil yang berukuran mikro (Sanjoto, 2005). Salah satu pengetahuan yang terdapat pada ilmu mikropaleontologi adalah planktonic foraminifera (fosil plankton). Fosil ini sangat banyak ditemukan di berbagai tempat, terutama pada batuan di dalam tanah, ataupun batuan yang terdapat di dalam laut. Tidak banyak orang yang mengetahui spesies apa saja yang ditemukan tersebut.

Daniel Alexander Octavianus Turang

Jurnal Ilmiah Teknologi Informasi Terapan

Volume IV, No 1, 15 Desember 2017 
Untuk mengetahui identitas dari fosil tersebut harus dilihat bentuk dan sifat-sifat fisiknya melalui mikroskop, kemudian bertanya kepada ahlinya ataupun membaca dari buku referensi. Hal tersebut memerlukan waktu yang relatif lebih lama bila dibandingkan dengan menggunakan sebuah sistem yang menggunakan teknologi komputer.

Teknologi komputer pada saat ini telah mengalami pekembangan yang sangat pesat dan menjadi kebutuhan penting bagi kehidupan manusia. Perkembangan yang pesat tersebut juga didukung oleh perangkat keras ataupun perangkat lunak yang semakin canggih. Oleh karena itu, manusia memanfaatkan komputer tidak hanya digunakan untuk membantu meringankan pekerjaan manusia, tetapi juga dapat menggantikan pekerjaan manusia. Sehingga para ahli komputer terus mencoba membuat komputer dapat berpikir dan bertindak seperti manusia, agar komputer dapat memiliki kecerdasan seperti manusia. Teknologi komputer yang memiliki kecerdasan seperti manusia disebut dengan istilah kecerdasan buatan (Artificial Intelligence).

Kecerdasan buatan adalah suatu ilmu yang mempelajari cara membuat komputer melakukan sesuatu seperti yang dilakukan oleh manusia. Salah satu cabang dari kecerdasan buatan adalah sistem pakar. Sistem pakar merupakan sistem yang menggabungkan pengetahuan dan penelusuran data untuk memecahkan masalah yang secara normal memerlukan keahlian manusia pada bidang tertentu. Pengetahuan tersebut dapat diperoleh dari seorang ahli atau pengetahuan yang umumnya terdapat pada buku, internet, dan orang yang mempunyai pengetahuan dalam suatu bidang tertentu. Semua pengetahuan dari seorang pakar, ataupun referensi tersebut dapat diubah kedalam bentuk teknologi komputer.

Berdasarkan latar belakang yang telah dijelaskan sebelumnya dibuatlah aplikasi untuk identifikasi planktonic foraminifera. Sehingga seluruh proses identifikasi planktonic foraminifera dikelola menjadi informasi yang bermanfaat. Diharapkan orang yang tertarik di bidang mikropaleontologi lebih mudah untuk menentukan jenis planktonic foraminifera dan aturannya serta mengetahui irisan umur dari batuan yang diteliti tanpa harus menghitung secata manual.

\section{KAJIAN LITERATUR}

\section{II.1 Sistem Pakar}

Dalam ilmu komputer, banyak ahli yang berkonsentrasi pada pengembangan kecerdasan buatan atau Artificial Intelligence (AI). AI adalah suatu studi khusus untuk membuat komputer berpikir dan bertindak seperti manusia. Salah satu implementasi AI dalam bidang komputer adalah sistem pakar.

Sistem pakar (expert system) adalah sistem yang berusaha mengadopsi pengetahuan manusi ke komputer, agar komputer dapat menyelesaikan masalah seperti yang biasa dilakukan oleh para ahli (Kusumadewi, 2003). Sistem pakar merupakan penggabungan pengetahuan dan penelusuran data untuk memecahkan masalah yang secara normal memerlukan keahlian manusia. Tetapi tujuan pengembangan sistem pakar sebenarnya bukan untuk menggantikan peran manusia, melainkan untuk menggabungkan pengetahuan manusia kedalam bentuk sistem, sehingga dapat digunakan oleh orang banyak.

Menurut Kusrini (2005), sistem pakar adalah sistem berbasis komputer yang menggunakan pengetahuan, fakta, dan teknik penalaran dalam memecahkan masalah yang biasanya hanya dapat dipecahkan oleh seorang pakar/ahli dalam suatu bidang. Sistem ini berusaha mengadopsi pengetahuan manusia ke komputer, agar komputer dapat menyelesaikan masalah seperti yang biasa dilakukan oleh para ahli. Implementasinya dapat menggunakan bahasa pemrograman tertentu dan database. Tujuan pengembangan sistem pakar sebenarnya bukan untuk menggantikan peran manusia, tetapi mensubstitusikan pengetahuan manusia ke dalam komputer, sehingga dapat digunakan oleh banyak orang. Diharapkan dengan sistem ini, orang awam dapat menyelesaikan masalah tertentu layaknya seorang ahli. Sedangkan bagi para ahli, sistem ini dapat digunakan sebagai asisten yang berpengalaman. Yang membedakan Sistem Pakar dengan Sistem Konvensional adalah knowledge base terpisah dari mekanisme pemrosesan (inference), dan perubahan pada rules dapat dilakukan dengan mudah (Kusrini, 2008).

Sistem pakar disusun oleh dua bagian utama, yaitu lingkungan pengembangan (development environment) dan lingkungan konsultasi (consultation environment). Lingkungan pengembangan sistem pakar digunakan untuk memasukkan pengetahuan pakar ke dalam sistem komputer, sedangkan lingkungan konsultasi

Daniel Alexander Octavianus Turang

Jurnal Ilmiah Teknologi Informasi Terapan

Volume IV, No 1, 15 Desember 2017 
digunakan oleh pengguna yang bukan pakar (awam), untuk menggali pengetahuan pakar (Arhami, 2005).

\section{II.2 Mikropaleontologi}

Mikropaleontologi merupakan cabang dari ilmu paleontologi yang mempelajari sisa-sisa organisme yang telah terlewatkan di alam berupa fosil yang berukuran mikro, sehingga biasa disebut mikrofosil. Pengetahuan yang dibahas antara lain adalah mikrofosil, klasifikasi, morfologi, ekologi, dan mengenai kepentingannya terhadap stratigrafi (Maha dkk, 2009).

Dalam mempelajari sifat-sifat dan strukturnya dilakukan dibawah mikroskop. Umumnya fosil ukurannya lebih dari $5 \mathrm{~mm}$ namun ada yang berukuran sampai $19 \mathrm{~mm}$ seperti genus fusulina yang memiliki cangkan-cangkang yang dimiliki organism, embrio, dari fosil-fosil makro serta bagian-bagian tubuh dari fosil makro yang mengamatinya menggunakan mikroskop serta sayatan tipis dari fosil-fosil, sifat fosil makro dari golongan foraminifera, kenyataannya foraminifera mempunyai fungsi untuk mempelajarinya (Jones, 1956).

\section{II.3 Foraminifera}

Foraminifera termasuk dalam mikrofosil yang berada pada Filum Protozoa yang mulai berkembang pada jaman Kambrium sampai Resen. Mayoritas anggotanya hidup pada lingkungan laut dan mempunyai ukuran $3 \pi \mathrm{m}$ sampai $3 \mathrm{~mm}$ (Haq \& Boersma, 1998). Menurut habitatnya, foraminifera dibagi menjadi foraminifera planktonic dan foraminifera bentonic.

Foraminifera planktonic merupakan jenis foraminifera yang terkelompokkan oleh organisme laut yang tidak terlalu dalam, yaitu plankton, sedangkan foraminifera bentik dikelompokkan oleh organisme laut yang lebih dalam, yaitu bentos. Dari dua jenis foraminifera ini lebih sering digunakan pada ilmu perminyakan dimana dari kedua jenis fosil itu identik dengan hidrokarbon yang terdapat pada trap (jebakan). Dalam geologi struktur dimana dapat digunakan untuk mengidentifikasi adanya sesar, kekar, serta lipatan.

\section{II.4 Sifat-sifat Fisik Planktonic Foraminifera}

Sifat-sifat fisik dari planktonic foraminifera yang menjadi acuan untuk mendeskripsikan spesies planktonic foraminifera, yaitu aperture, bentuk test, hiasan pada aperture, susunan kamar, bentuk kamar, hiasan pada test, hiasan pada peri, hiasan pada suture, dan hiasan pada umbilicus (Maha dkk, 2009).
1. Aperture

Aperture adalah lubang utama dari test foraminifera yang terletak pada kamar terakhir. Khusus planktonic foraminifera mempunyai bentuk aperture maupun variasinya yang lebih sederhana. Umumnya mempunyai bentuk aperture utama interiomarginal yang terletak pada dasar kamar terakhir (septal face) dan melekuk kedalam, terdapat pada bagian ventral.

2. Bentuk Test

Bentuk test adalah bentuk keseluruhan dari cangkang foraminifera.

3. Susunan Kamar

Susunan kamar planktonic foraminifera dibagi menjadi :

a) Planispiral, yaitu sifatnya berputar pada suatu bidang. Semua kamar terlihat serta jumlah kamar ventral dan dorsal sama. Contoh : Hastigerina.

b) Trochospiral, yaitu sifat berputar tidak pada satu bidang, tidak semua kamar terlihat, pandangan serta jumlah kamar ventral dan dorsal tidak sama. Contohnya : Globigerina.

c) Streptospiral, yaitu sifat mula-mula trochospiral, kemudian planispiral menutupi sebagian atau seluruh kamar-kamar sebelunya. Contohnya : Pulleniatina.

\section{Bentuk Kamar}

Bentuk kamar merupakan bentuk masingmasing kamar pembentuk test. Bentuk kamar yang diidentifikasikan pada planktonic foraminifera adalah hemispherical, Angular Rhomboid, Angular Conical, Radial Elongate, Claved, Flatulose, Tabular, Semicirculer, Spherical, Pyriform, Globular, Oved, dan Angular Truncate.

5. Ornament (hiasan) foraminifera

Ornament atau hiasan juga dapat digunakan sebagai penciri khas untuk genus atau spesies tertentu. Berdasarkan letak hiasannya dapat dibagi menjadi :

a) Hiasan pada suture

1) Bridge, yaitu bentuk suture yang menyerupai jembatan.

2) Limbate, yaitu bentuk suture yang tebal.

3) Retral Processes, yaitu suture yang berbentuk zig-zag.

4) Raised Bosses, yaitu bentuk suture memiliki tonjolan bulat.

Daniel Alexander Octavianus Turang

Jurnal Ilmiah Teknologi Informasi Terapan

Volume IV, No 1, 15 Desember 2017 
b) Hiasan pada umbilicus

1) Deeply Umbilicus, yaitu umbilicus yang berlubang dalam.

2) Open Umbilicus, yaitu umbilicus yang terbuka lebar.

3) Umbilical Flap, yaitu umbilicus yang mempunyai penutup.

4) Ventral Umbo, yaitu umbilicus yang menonjol di permukaan.

c) Hiasan pada peri

1) Keel, yaitu lapisan tipis dan bening.

2) Spine, yaitu bentuk menyerupai duri.

d) Hiasan pada aperture

1) Lip/rim, yaitu bibir aperture yang menebal.

2) Flap, yaitu bentuk menyerupai anak lidah.

3) Tooth, yaitu berbentuk menyerupai gigi.

4) Bulla, yaitu aperture yang segi enam yang teratur.

5) Tegilla, yaitu bentuk aperture yang tidak teratur.

e) Hiasan pada permukaan test

1) Smooth, yaitu permukaan yang licin.

2) Punctate, yaitu permukaannya memiliki bintik-bintik.

3) Reticulate, yaitu permukaannya seperti sarang madu.

4) Pustulose, permukaan dengan tonjolantonjolan bulat.

5) Canceliate, permukaan dengan tonjolan yang memanjang.

6) Axial Costae, permukaan dengan garis searah sumbu.

Spiral Costae, permukaan dengan garis searah putaran kamar.

\section{II.5 Umur Relatif}

Umur geologi merupakan skala umur yang menunjukkan jaman-jaman yang telah berlangsung sejak bumi terbentuk hingga kehidupan saat ini, skala waktu yang digunakan disebut skala waktu geologi. Skala waktu geologi digunakan oleh para ahli geologi dan ilmuwan untuk menjelaskan waktu dan hubungan antar peristiwa yang terjadi sepanjang sejarah bumi.

Cara menentukan umur relatif pada umumnya didasarkan atas dijumpainya fosil didalam batuan. Didalam mikropaleontologi cara menentukan umur relatif yaitu dengan menggunakan foraminifera kecil planktonic (Maha dkk, 2009). Disamping jumlah genus sedikit, plankton sangat peka terhadap perubahan kadar garam, hal ini menyebabkan hidup suatu spesies mempunyai kisaran umur yang pendek, sehingga baik untuk penciri umur suatu lapisan batuan.

Biozonasi foraminifera planktonik yang popular dan sering digunakan di Indonesia adalah Zonasi Blow. Biozonasi foraminifera planktonik dapat dilihat pada tabel 1 (Blow, 1969).

Tabel 1. Biozonasi Foraminifera Planktonik

\begin{tabular}{|c|c|c|}
\hline \multicolumn{3}{|c|}{ Planktonic } \\
\hline \multirow{4}{*}{ Oligosen } & $\mathrm{P}$ & $\mathrm{N}$ \\
\hline & 20 & 1 \\
\hline & 21 & 2 \\
\hline & 22 & 3 \\
\hline \multirow{15}{*}{ Miosen } & & 4 \\
\hline & & 5 \\
\hline & Awal & 6 \\
\hline & & 7 \\
\hline & & 8 \\
\hline & & 9 \\
\hline & & 10 \\
\hline & & 11 \\
\hline & lengah & 12 \\
\hline & & 13 \\
\hline & & 14 \\
\hline & & 15 \\
\hline & Albir & 16 \\
\hline & Aknir & 17 \\
\hline & & 18 \\
\hline \multirow{3}{*}{ Pliosen } & Awal & 19 \\
\hline & Albir & 20 \\
\hline & AKmII & 21 \\
\hline \multirow{2}{*}{ Pleistosen } & & 22 \\
\hline & & 23 \\
\hline
\end{tabular}

Berdasarkan biozonasi foraminifera planktonik menurut Blow tersebut, setiap fosil plankton di input-kan kedalam tabel, dan rentang umur setiap fosil sudah terdeskripsikan barada pada umur ke-berapa. Setelah semua fosil plankton yang terdapat pada batuan telah terdeskripsi, maka umur relatif dari sebuah batuan dapat diketahui dengan menghitung berapa banyak rentang umur yang sama, apabila dibandingkan pada setiap fosil plankton. Rentang umur yang terbanyak merupakan umur relatif dari sebuah batuan. Gambaran untuk mengetahui umur relatif dari suatu batuan dapat dilihat pada gambar 1.

Daniel Alexander Octavianus Turang

Jurnal Ilmiah Teknologi Informasi Terapan

Volume IV, No 1, 15 Desember 2017 


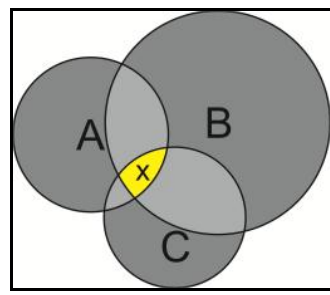

Gambar 1. Gambaran proses irisan umur relatif

Gambar 1 merupakan irisan dari himpunan A, himpunan $\mathrm{B}$, dan himpunan $\mathrm{C}$, sedangkan $\mathrm{X}$ adalah hasil dari $A \cap B \cap C$. Sehingga $X$ dapat dimaksudkan sebagai range dari umur relatif yang ingin ditampilkan kepada user. Untuk contoh implementasi untuk proses irisan umur relatif dapat dilihat pada tabel 2 .

Contoh implementasi untuk proses irisan umur relatif pada tabel hanya mengambil 3 contoh planktonic yaitu, plankton $\mathrm{A}$, plankton $\mathrm{B}$, dan plankton C. Dimana plankton A memiliki range umur antara $\mathrm{N} 9-\mathrm{N} 23$, plankton $\mathrm{B}$ memiliki range umur antara $\mathrm{N} 14-\mathrm{N} 23$, dan plankton $\mathrm{C}$ memiliki range umur antara $\mathrm{N} 12-\mathrm{N} 18$. Maka umur relatif dari ketiga jenis planktonic tersebut berada pada kisaran umur N $14-\mathrm{N} 18$.

Tabel 2. Contoh Implementasi Proses Irisan Umur Relatif

\begin{tabular}{|c|c|c|c|c|c|}
\hline \multicolumn{3}{|c|}{ Planktonic } & \multirow[t]{2}{*}{ Plankton A } & \multirow{2}{*}{ Plankton B } & Plankton C \\
\hline \multirow{4}{*}{ Oligosen } & $\mathrm{P}$ & $\mathrm{N}$ & & & \\
\hline & 20 & 1 & & & \\
\hline & 21 & 2 & & & \\
\hline & 22 & 3 & & & \\
\hline \multirow{15}{*}{ Miosen } & \multirow{5}{*}{ Awal } & 4 & & & \\
\hline & & 5 & & & \\
\hline & & 6 & & & \\
\hline & & 7 & & & \\
\hline & & 8 & & & \\
\hline & \multirow{6}{*}{ Tengah } & 9 & 1 & & \\
\hline & & 10 & & & \\
\hline & & 11 & & & \\
\hline & & 12 & & & I \\
\hline & & 13 & & & \\
\hline & & 14 & & I & \\
\hline & \multirow{4}{*}{ Akhir } & 15 & & & \\
\hline & & 16 & & & \\
\hline & & 17 & & & \\
\hline & & 18 & & & $t$ \\
\hline \multirow{3}{*}{ Pliosen } & Awal & 19 & & & \\
\hline & \multirow{2}{*}{ Akhir } & 20 & & & \\
\hline & & 21 & & & \\
\hline \multirow{2}{*}{\multicolumn{2}{|c|}{ Pleistosen }} & 22 & & & \\
\hline & & 23 & & & \\
\hline
\end{tabular}

\section{II.6 Metode Inferensi Forward Chaining}

Pada inferensi dengan metode forward chaining penelusuran akan dimulai dari anteseden yaitu permasalahan yang dihadapi. Pemrosesan akan merupakan serangkaian konsekuensi berupa irisan permasalahan dengan penyebab dan perbaikannya (S.N. Mohammad \& A. Y. Bani Hashim, 2015). Metode inferensi forward chaining disebut juga data driven, dimulai dengan fakta-fakta dan menelusuri aturan-aturan yang sesuai sampai diperoleh kesimpulan. Model dari sistem forward chaining dapat dilihat pada gambar 2 (Chakraborty, 2015).

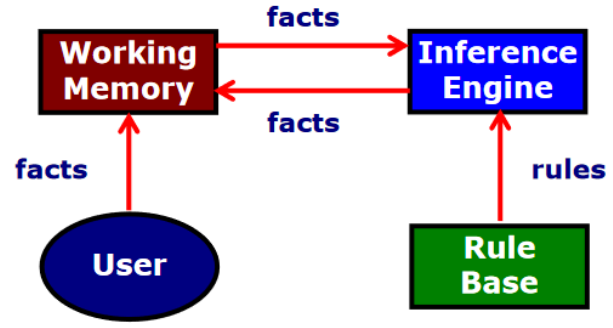

Gambar 2. Model sistem forward chaining

Fakta-fakta disimpan dalam memori kerja. Aturan-aturan berupa pasangan kondisi-aksi

Daniel Alexander Octavianus Turang

Jurnal Ilmiah Teknologi Informasi Terapan

Volume IV, No 1, 15 Desember 2017 
menunjukkan aksi yang akan dilakukan ketika fakta tertentu muncul dalam memori kerja. Aksi biasanya termasuk penambahan dan penghapusan fakta dari memori kerja (Chakraborty, 2015).

Algoritma umum dari metode forward chaining adalah sebagai berikut (Chakraborty, 2015):

Ulangi

* Kumpulkan aturan yang kondisinya sesuai dengan

fakta yang ada didalam memori kerja

* Lakukan aksi sesuai aturan tersebut

(menambahkan / menhapus fakta di memori kerja)

Sampai masalah terselesaikan atau tidak ada lagi

kondisi yang sesuai

\section{AnAlisis Dan Desain}

\section{III.1 Analisis Sistem}

Sistem pakar yang akan dibangun merupakan suatu sistem informasi yang berbasis komputer dengan memanfaatkan teknologi kecerdasan buatan (artificial intelligence) yang berfungsi sebagai sistem alat bantu atau pemberi rekomendasi dari proses identifikasi planktonic foraminifera kepada user. Data rekomendasi yang dihasilkan oleh sistem ini dilengkapi dengan nama spesies planktonic foraminifera, nama genus, gambar planktonic foraminifera, beserta sifat-sifat fisik dari planktonic tersebut sehingga user dapat mengetahui spesies planktonic foraminifera apa yang ditemukan.

Sistem akan menganalisa jawaban dari setiap pertanyaan yang diberikan, sehingga diperoleh hasil dari identifikasi berdasarkan basis pengetahuan yang ada dalam sistem pakar ini. Sebelum menganalisa jawaban, sistem terlebih dahulu memberikan sejumlah pertanyaan dan pilihan tentang sifat-sifat fisik planktonic foraminifera yang ditemukan berdasarkan aperture, bentuk test, hiasan aperture, susunan kamar, bentuk kamar, hiasan test, hiasan peri-peri, hiasan suture, hiasan umbilicus kepada user melalui interface. Kemudian sistem akan menganalisa jawaban dari user dengan melakukan proses pelacakan pada basis pengetahuan, sehingga didapatkan suatu hasil identifikasi jenis planktonic foraminifera berdasarkan sifat-sifat fisiknya.

Sistem ini dilengkapi dengan fitur perhitungan umur relatif dari suatu batuan. Dimana batuan tersebut mengandung beberapa jenis planktonic foraminifera, dan setiap planktonic foraminifera tersebut telah memiliki range umur. Tugas dari user hanya memasukkan planktonic foraminifera apa saja yang terdapat pada batuan tersebut. Dan setelah itu, sistem akan menghitung range umur relatif berdasarkan range umur dari setiap planktonic foraminifera yang telah dimasukkan.

Adapun langkah-langkah yang dilakukan dalam pembuatan sistem pakar adalah sebagai berikut:

1. Proses pembuatan Akuisisi Pengetahuan dengan mengelompokan masing-masing sifat fisik dan spesies planktonic foraminifera.

2. Proses pembuatan representasi pengetahuan yang tersusun atas kaidah-kaidah yang mengikuti pola : IF [kondisi] THEN [aksi]. Representasi pengetahuan disusun berdasarkan data pada akuisisi pengetahuan.

3. Proses pembuatan pohon pelacakan untuk menentukan spesies planktonic foraminifera dengan menggunakan proses telusuri Depth-First Search yang akan menelusuri kaidah secara mendalam.

4. Proses pembuatan sistem. Sistem pakar dibangun dengan berbais web. Web digunakan sebagai alat bantu untuk mengakses dan mengelola data sistem pakar.

\section{III.2 Akuisisi Pengetahuan}

Proses akuisisi pengetahuan dilakukan dengan cara mengklarifikasikan pengetahuan tentang jenis planktonic foraminifera disertai dengan sifat-sifat fisik yang dimilikinya. Sumber-sumber pengetahuan didapat dari seorang pakar mikropalenteologi dan buku-buku tentang mikropalenteologi.

Pengetahuan yang telah terkumpul kemudian dikodekan, setelah dikodekan pengetahuan tersebut harus tetap ditinjau ulang kebenarannya oleh seorang pakar atau suber-sumber lainnya untuk pembuktian kebenarannya. Tabel akuisisi pengetahuan jenis planktonic foraminifera berdasarkan sifat-sifat fisik yang dimilikinya dapat dilihat pada tabel 3 (Postuma, 1971). Tabel tersebut menunjukkan sifat-sifat fisik apa saja yang dimiliki oleh setiap spesies planktonic foraminifera yang terdaftar.

Daniel Alexander Octavianus Turang

Jurnal Ilmiah Teknologi Informasi Terapan

Volume IV, No 1, 15 Desember 2017 
Tabel 3. Tabel Akuisisi Pengetahuan

\begin{tabular}{|c|c|c|c|c|c|c|c|c|c|c|c|c|c|c|}
\hline \multirow[t]{2}{*}{ No } & Sifat Fisik & 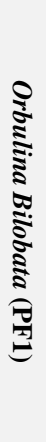 & 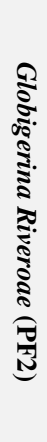 & 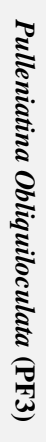 & 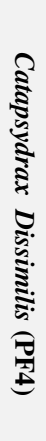 & 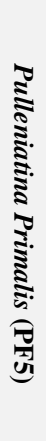 & 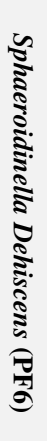 & 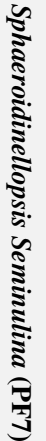 & 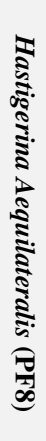 & 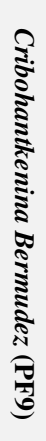 & 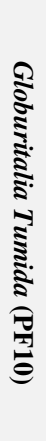 & 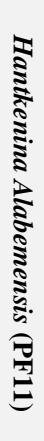 & 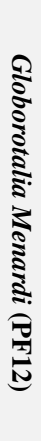 & 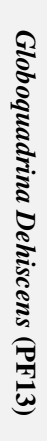 \\
\hline & \multicolumn{14}{|l|}{ Aperture } \\
\hline 3 & PAI Equatorial (AP3) & & & $*$ & & & & & & $*$ & & $*$ & & \\
\hline \multirow[t]{2}{*}{4} & Small Opening (AP4) & $*$ & & & & & & & & & & & & \\
\hline & \multicolumn{14}{|l|}{ Bentuk Test } \\
\hline 1 & Biumbilicate (BT1) & & & & & & & & $*$ & $*$ & & $*$ & & \\
\hline 2 & Biconvex (BT2) & & & & & & & & & & $*$ & & $*$ & \\
\hline 3 & Spherical (BT3) & $*$ & & $*$ & & $*$ & & & & & & & & \\
\hline \multirow[t]{2}{*}{4} & Globural (BT4) & & $*$ & & $*$ & & $*$ & $*$ & & & & & & \\
\hline & \multicolumn{14}{|l|}{ Hiasan Aperture } \\
\hline 1 & Flape (HA1) & & & & & & & & & & & & & $*$ \\
\hline 2 & Tooth (HA2) & & & & & & & & & & & $*$ & & \\
\hline 3 & \multicolumn{14}{|l|}{ Bentuk Kamar } \\
\hline 1 & Tubulospinate (BK1) & & & & & & & & & $*$ & & $*$ & & \\
\hline 2 & Spherical (BK2) & $*$ & & & & & & & & & & & & $*$ \\
\hline \multirow[t]{2}{*}{3} & Globular (BK3) & & $*$ & $*$ & $*$ & $*$ & $*$ & $*$ & $*$ & & $*$ & & & \\
\hline & \multicolumn{14}{|l|}{ Hiasan Test } \\
\hline 1 & Punctate (HT1) & $*$ & $*$ & & $*$ & $*$ & & & $*$ & $*$ & $*$ & $*$ & $*$ & $*$ \\
\hline \multirow[t]{2}{*}{2} & Smooth (HT2) & & & $*$ & & & $*$ & $*$ & & & & & & \\
\hline & \multicolumn{14}{|l|}{ Hiasan Peri } \\
\hline 1 & Keel (HP1) & & & & & & & & & & $*$ & & $*$ & \\
\hline \multirow[t]{2}{*}{2} & Spine (HP2) & & & & & & & & & $*$ & & $*$ & & \\
\hline & \multicolumn{14}{|l|}{ Hiasan Suture } \\
\hline 1 & Bridge (HS1) & & & & & & $*$ & & & & & & & \\
\hline \multirow[t]{2}{*}{2} & Limbate (HS2) & & & & & & & & & & $*$ & & & \\
\hline & Hiasan Umbilicus & & & & & & & & & & & & & \\
\hline 1 & Deeply Umbilicus (HU1) & & & & & & & & & & & & & $*$ \\
\hline 2 & Open Umbilicus (HU2) & & & & & & $*$ & & & & & & & \\
\hline
\end{tabular}

\section{III.3 Representasi Pengetahuan}

Representasi pengetahuan berisi pengetahuan penting untuk pengertian, formulasi dan pemecahan masalah. Representasi pengetahuan berisi kaidahkaidah untuk penarikan kesimpulan yang merupakan hasil proses penelusuran data.
Jenis representasi pengetahuan yang digunakan adalah metode kaidah produksi. Representasi ini tersusun atas kaidah-kaidah yang mengikuti pola : IF [kondisi] THEN [aksi]. Kondisi yang dimaksud adalah kondisi yang berupa sifat-sifat fisik dari fosil plankton, sedangkan aksi yang

Daniel Alexander Octavianus Turang

Jurnal Ilmiah Teknologi Informasi Terapan

Volume IV, No 1, 15 Desember 2017 
dimaksud adalah nama fosil plankton. Tabel representasi pengetahuan dapat dilihat pada tabel 4 dibawah ini :

Tabel 4. Tabel Representasi Pengetahuan

\begin{tabular}{|l|l|}
\hline No & \multicolumn{1}{|c|}{ Aturan } \\
\hline 1 & IF AP4 AND BT3 AND SK2 AND BK2 AND HT1 THEN PF1 \\
\hline 2 & IF AP1 AND BT4 AND HA3 AND SK2 AND BK3 AND HT1 THEN PF2 \\
\hline 3 & IF AP3 AND BT3 AND HA3 AND SK3 AND BK3 AND HT2 THEN PF3 \\
\hline 4 & IF AP1 AND BT4 AND HA4 AND SK2 AND BK3 AND HT1 THEN PF4 \\
\hline 5 & IF AP2 AND BT3 AND HA3 AND SK2 AND BK3 AND HT1 THEN PF5 \\
\hline 6 & IF AP1 AND BT4 AND HA5 AND SK2 AND BK3 AND HT2 AND HS1 AND HU2 THEN PF6 \\
\hline 7 & IF AP1 AND BT4 AND HA3 AND SK2 AND BK3 AND HT2 THEN PF7 \\
\hline 8 & IF AP2 AND BT1 AND HA3 AND SK1 AND BK3 AND HT1 THEN PF8 \\
\hline 9 & IF AP3 AND BT1 AND HA3 AND SK1 AND BK1 AND HT1 AND HP2 THEN PF9 \\
\hline 10 & IF AP2 AND BT2 AND HA3 AND SK2 AND BK3 AND HT1 AND HP1 AND HS2 THEN PF10 \\
\hline 11 & IF AP3 AND BT1 AND HA2 AND SK1 AND BK1 AND HT1 AND HP2 THEN PF11 \\
\hline 12 & IF AP2 AND BT2 AND HA3 AND SK2 AND HT1 AND HP1 THEN PF12 \\
\hline 13 & IF AP1 AND HA1 AND SK2 AND BK2 AND HT1 AND HU1 THEN PF13 \\
\hline
\end{tabular}

\section{III.4 Pohon Pelacakan}

Pohon pelacakan yang digunakan dalam sistem ini mengikuti pola pelacakan maju (forward chaining). Pohon pelacakan ini dimulai dengan memberikan pertanyaan tentang sifat-sifat fisik yang dimiliki planktonic foraminifera, kemudian dari sifatsifat fisik yang dimasukkan oleh user akan diperoleh kesimpulan tentang spesies planktonic foraminifera apa yang terdapat sifat-sifat tersebut.

Berikut ini adalah pohon pelacakan dalam menentukan jenis planktonic foraminifera yaitu dengan menggunakan proses pencarian Depth-First Search yang akan menelusuri kaidah secara mendalam. Pohon pelacakan pada sistem ini dapat dilihat pada gambar 3 .

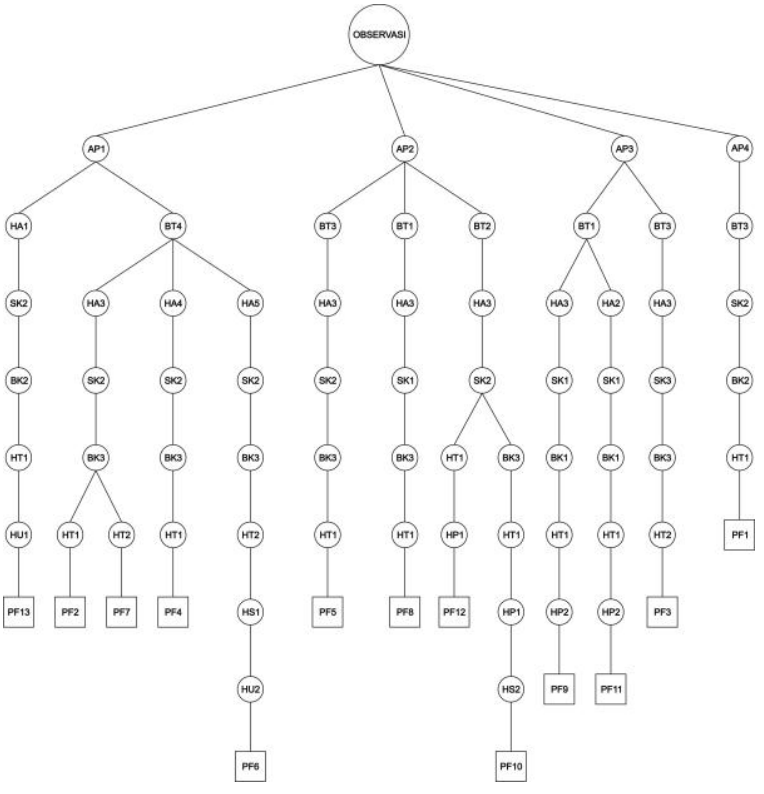

Gambar 3. Pohon Pelacakan

\section{III.5 Context Diagram}

Context diagram merupakan gambaran garis besar proses dari sistem yang akan dibangun ini. Pada DFD level 0 diatas, terdapat 2 entitas dan 1 proses. Entitas pertama adalah admin, dan entitas kedua adalah user. Pada entitas admin terdapat aliran data yang keluar dan masuk yaitu data login, data sifat

Daniel Alexander Octavianus Turang

Jurnal Ilmiah Teknologi Informasi Terapan

Volume IV, No 1, 15 Desember 2017 
fisik planktonic, data planktonic, data aturan, dan data umur. Sedangkan aliran data pada entitas user juga terdapat aliran data keluar dan masuk untuk data sifat fisik planktonic, data planktonic, data aturan, dan data umur. Data sifat fisik planktonic terdiri dari susunan kamar, bentuk test, bentuk kamar, aperture, hiasan pada permukaan test, hiasan pada aperture, hiasan pada suture, hiasan pada umbilical, hiasan pada peri. Context diagram dapat dilihat pada gambar 4.

\section{III.6 Entity Relationship Diagram (ERD)}

Basis data dalam sistem ini menggunakan model basis data relasional, dimana tabel-tabel dalam basis data tersebut saling berhubungan. Diagram relasi entitas menggambarkan hubungan entitas yang terdapat salah satu tabel dengan entitas pada tabel yang lain.

Komponen-komponen yang ada pada ERD yang berupa himpunan entitas dan himpunan relasi akan ditransformasikan menjadi tabel-tabel, sedangkan atributnya dinyatakan sebagai field dari tabel-tabel tersebut. Entity relationship diagram pada basis data sistem ini dapat dilihat pada gambar 5 .

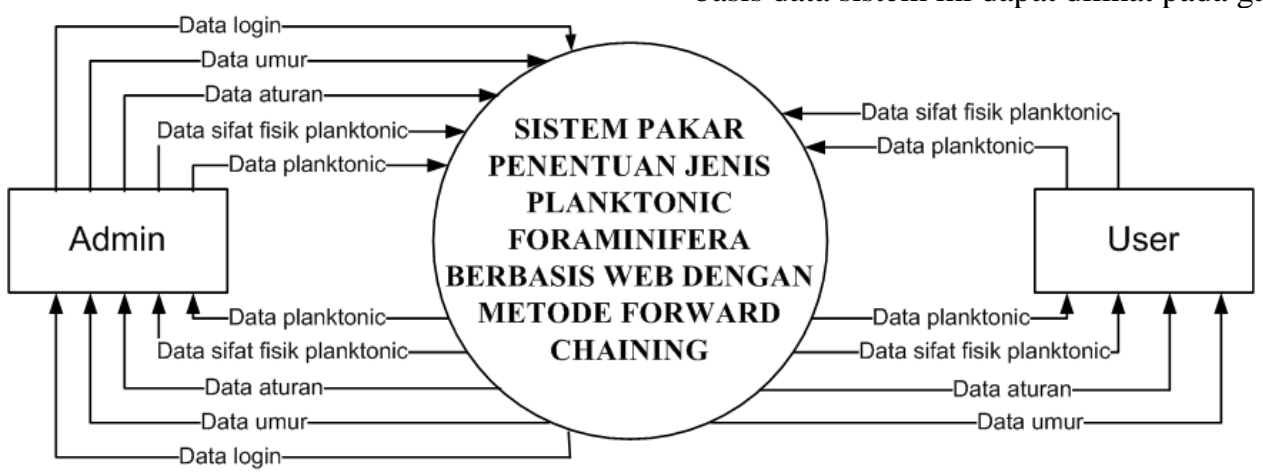

Gambar 4. Context diagram

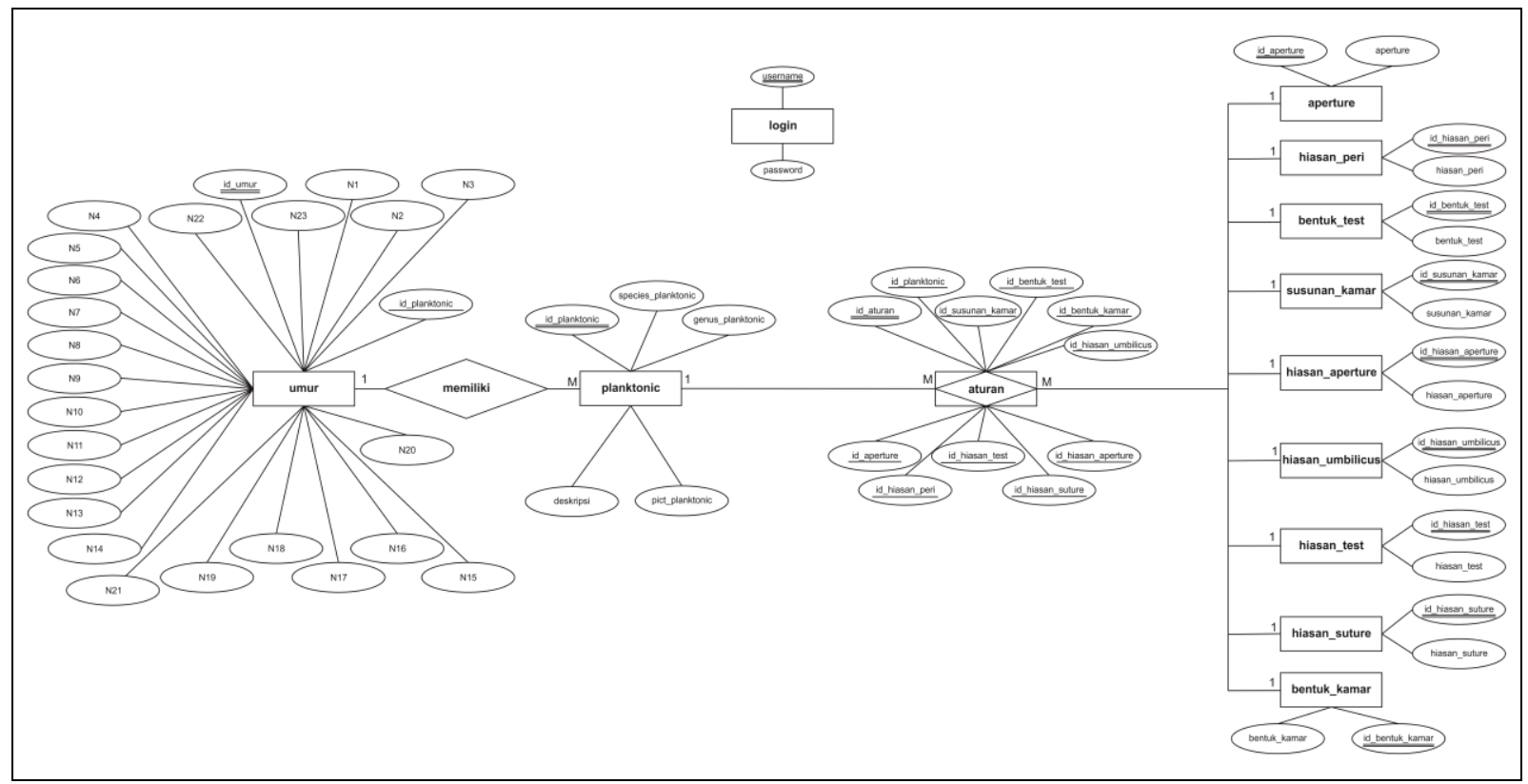

Gambar 5. Entity Relationship Diagram (ERD)

Daniel Alexander Octavianus Turang

Jurnal Ilmiah Teknologi Informasi Terapan

Volume IV, No 1, 15 Desember 2017 


\section{III.7 Relasi Antar Tabel}

Perancangan tabel-tebel dalam sistem ini dapat ditransformasikan ke himpunan tabel-tabel yang saling berhubungan, yang menunjukkan adanya hubungan antara sejumlah entitas yang berasal dari himpunan entitas yang berbeda. Pada relasi antar tabel juga akan diperlihatkan bagaimana kardinalitas antara entitas satu dengan entitas lainnya yang saling berhubungan. Relasi antar tabel pada penelitian ini dapat dilihat pada gambar 6 .

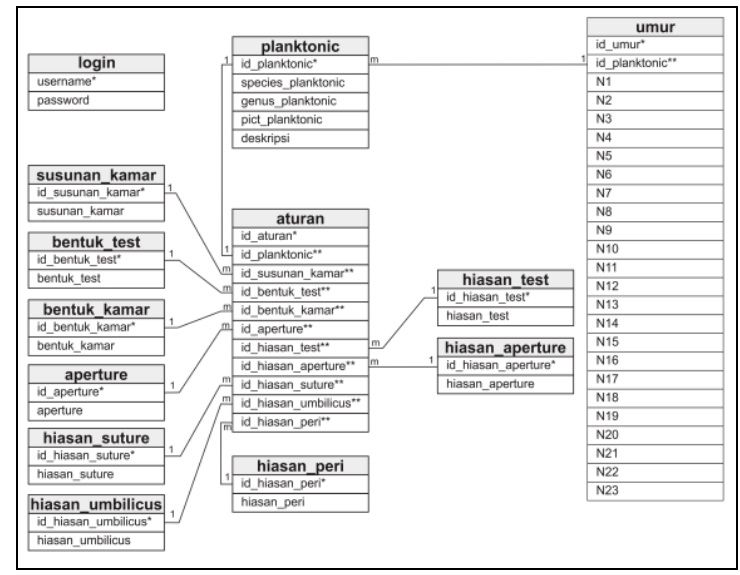

Gambar 6. Relasi Antar Tabel

\section{IMPLEMENTASI}

Tampilan halaman yang digunakan user merupakan tampilan-tampilan dimana user dapat melakukan interaksi dengan sistem ini. Tampilantampilan halaman tersebut antara lain halaman homepage user, halaman konsultasi, halaman hasil konsultasi, halaman irisan umur relatif, halaman hasil perhitungan umur relatif, halaman daftar fossil.

Halaman hompage user merupakan halaman awal ketika user memasukkan alamat website untuk pertama kali. Tampilan halaman hompage user dapat dilihat pada gambar 7 .

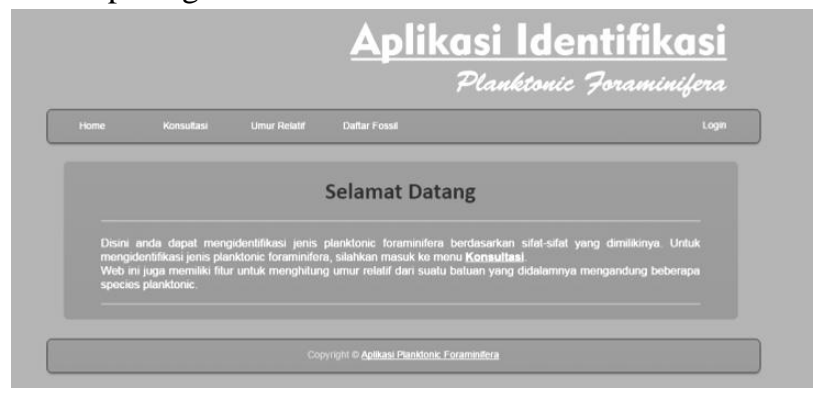

Gambar 7. Halaman Hopepage User
Halaman konsultasi merupakan tampilan yang berfungsi untuk meenampilkan sifat-sifat fisik planktonic foraminifera, sehingga user dapat memasukkan sifat-sifat fisik planktonic foraminifera untuk dapat mengetahui jenis dari planktonik foraminifera. Halaman konsultasi yang akan ditampilkan adalah berdasarkan aturan-aturan yang telah ditentukan dalam representasi pengetahuan. Tampilan halaman konsultasi dapat dilihat pada gambar 8.

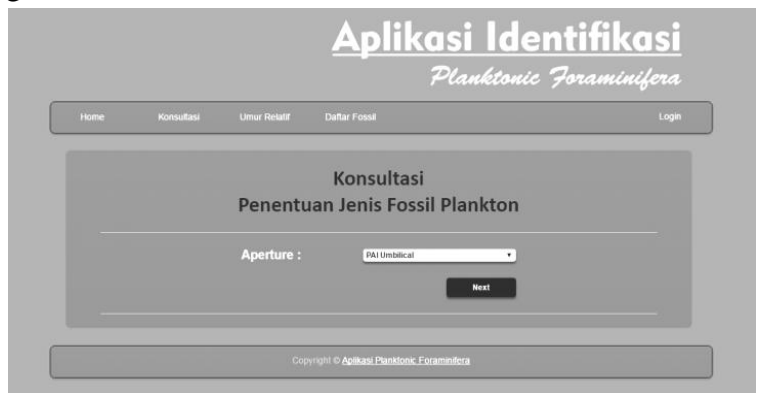

Gambar 8. Halaman Konsultasi

Halaman hasil konsultasi adalah tampilan yang muncul ketika user telah selesai memasukkan sifat-sifat fisik planktonic foraminifera. Tampilan ini akan menampilkan ciri-ciri planktonic beserta aturannya. Tampilan halaman hasil konsultasi dapat dilihat pada gambar 9 .

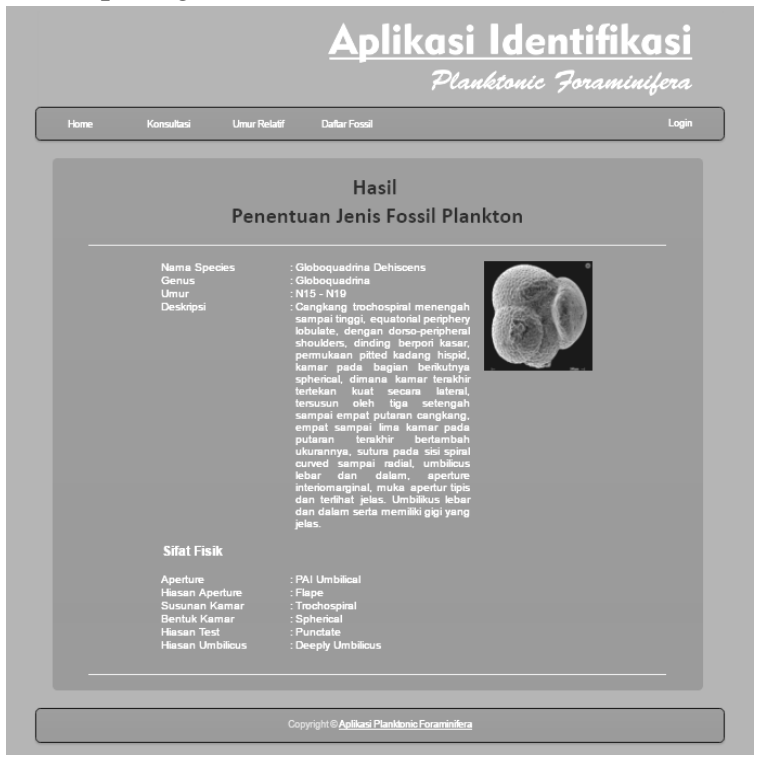

Gambar 9. Halaman Hasil Konsultasi

Halaman irisan umur relatif ini merupakan tampilan untuk menentukan umur relatif dari suatu batuan. Tampilan halaman irisan umur relatif dapat dilihat pada gambar 10 .

Daniel Alexander Octavianus Turang

Jurnal Ilmiah Teknologi Informasi Terapan

Volume IV, No 1, 15 Desember 2017 


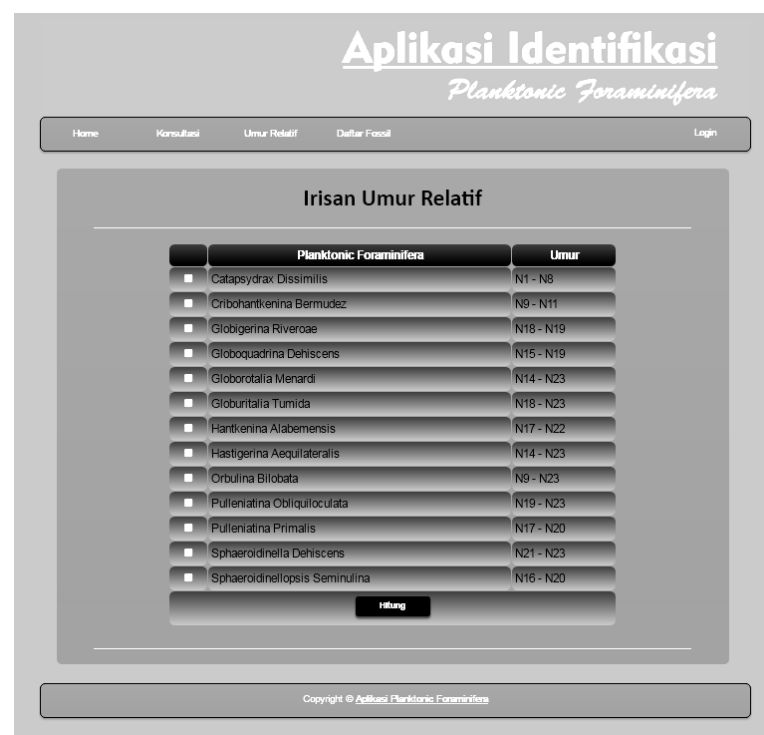

Gambar 10. Halaman Irisan Umur Relatif

Halaman hasil irisan umur relatif merupakan tampilan untuk melihat umur relatif dari suatu batuan berdasarkan planktonic foraminifera yang telah dimasukan oleh user. Tampilan halaman hasil irisan umur relatif dapat dilihat pada gambar 11 .

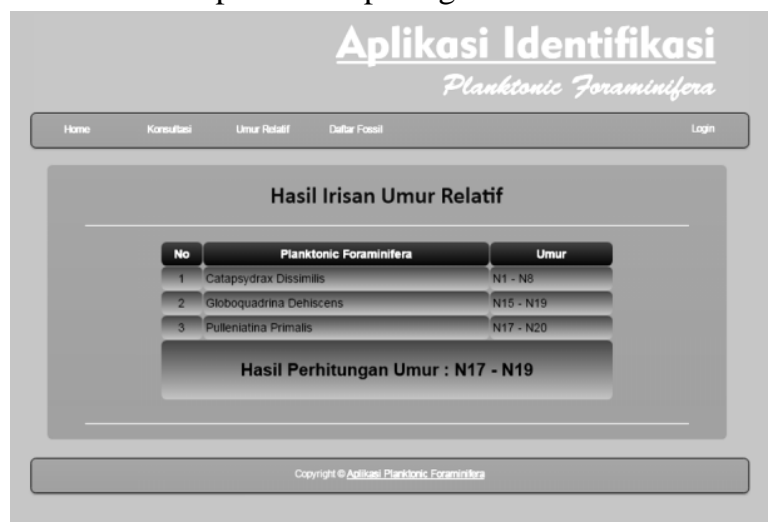

Gambar 11. Halaman Hasil Irisan Umur Relatif

Halaman daftar fosil ini merupakan tampilan untuk melihat semua planktonic foraminifera yang telah terdaftar pada sistem. Tampilan halaman daftar fosil dapat dilihat pada gambar 12 .

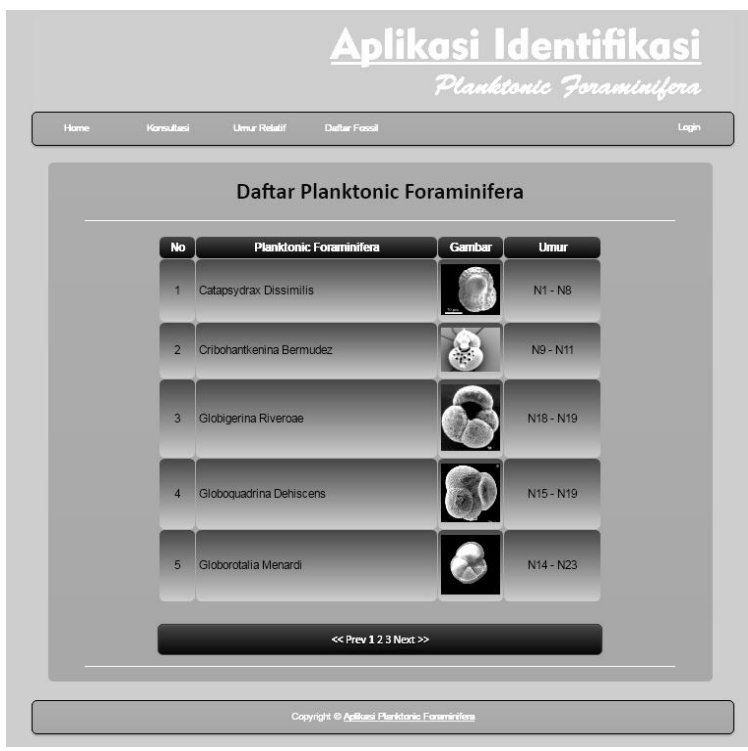

Gambar 12. Halaman Daftar Fosil

\section{KESIMPULAN}

Berdasarkan dari hasil analisis, perancangan dan implementasi yang telah dilakukan, maka telah dihasilkan suatu aplikasi untuk menentukan jenis planktonic foraminifera berdasarkan sifat-sifat fisik yang dimilikinya. Kualitas sebuah sistem pakar sangat bergantung kepada kualitas dari pengetahuan pakar yang dapat direpresentasikan kedalam basis pengetahuannya. Pada sistem pakar telah dilengkapi dengan fitur untuk menentukan umur relatif dari sebuah batuan.

Berdasarkan sistem pakar yang telah dibangun, saran yang diajukan berkaitan dengan pengembangan penelitian selanjutnya yaitu sifat-sifat fisik yang menjadi tolak ukur tidak hanya susunan kamar, bentuk test, bentuk kamar, aperture, hiasan pada permukaan test, hiasan pada aperture, hiasan pada suture, hiasan pada umbilical, hiasan pada peri, tetapi juga dapat menambahkan sifat-sifat fisik yang lebih spesifik lagi, sehingga penentuan spesies planktonic foraminifera lebih akurat, dan sistem ini juga dapat ditambahkan menu forum diskusi, sehingga user dapat berinteraksi dan berdiskusi dengan user lainnya ataupun user dengan admin. 


\section{REFERENSI}

Sanjoto Siwi, Defri H, \& Sri P.K., 2005, Buku Petunjuk Praktikum Mikropaleontologi, Yogyakarta: ISTA.

Kusumadewi, Sri, 2003, Artificial Intelligence: Teknik dan Aplikasinya, Yogyakarta: Graha Ilmu.

Kusrini, 2005, Sistem Pakar Teori dan Aplikasi, Yogyakarta: Andi Offset.

Kusrini, 2008, Aplikasi Sistem Pakar Menentukan Faktor Kepastian Pengguna dengan Metode Kuantifikasi Pertanyaan, Yogyakarta: Andi Offset.

Arhami, M., 2005, Konsep Dasar Sistem Pakar, Yogyakarta: Andi Offset.

Maha, Mahap., dkk, 2009, Buku Panduan Praktikum Mikropaleontologi, Laboratorium Mikropaleontologi, Jurusan Teknik Geologi UPN "Veteran" Yogyakarta, Yogyakarta.

Jones, D.J, 1956, Introduction to Microfossils, New York, London: Hafner Publishing Company.

Haq B. U., \& Boersma A. , 1998, Introduction to Marine Micropaleontology, Elsevier Science, Singapore, pp. 376.

Blow, W.H, 1969, Late Middle Eocene to Recent Planktonic Foraminifera Biostratigraphy Conf, Planktonic Microfossil, Geneva, Pro.Leiden, E.J Bull v.1.

S.N. Mohammad \& A. Y. Bani Hashim, 2015, Forward-chaining Approach to Expert System for Machine Maintenance, Proceedings of Mechanical Engineering Day.

RC Chakraborty, 2015, Knowledge Representation: AI Course Lecture, Retrieved Agustus 2017, from http://www.myreaders.info/html/artificial_inte lligence.html.

Postuma, J.A, 1971, Manual of Planktonic Foraminifera, Amsterdam: Elsevier Pub. Co. 